\title{
About chemistry of tourmaline from Mnogovershinnoe ore deposit (Khabarovsk Krai, Far East)
}

\author{
Ivan Andreevich BAKSHEEV", \\ Evgeniy Alekseevich VLASOV"
}

Lomonosov Moscow State University, Moscow, Russia

Relevance of the work is due to the need to study the mineralogy of gold deposits in the Russian Far East, information about which is extremely scarce.

Purpose of the work: study of the chemical composition of tourmaline from Mnogovershinnoe ore deposit, Khabarovsk Krai (Far East).

Methodology of research: The chemical composition of minerals and BSE images were obtained using a Jeol JSM-6480 electron microscope equipped with an Inca Energy-350 EDS (analyst is N. N. Koshlyakova, Department of Petrology, Lomonosov Moscow State University). Electron microscope shooting environment: accelerating voltage is $15 \mathrm{kV}$, measuring current for the sample is $30 \pm 0.1 \mathrm{nA}$. XPP corrections were used for the adjustment procedure (INCA program, version 17a).

Results. The obtained data show that tourmalines of the Mnogovershinnoe deposit differ in their chemical composition and type of substitution. All studied tourmalines by these parameters can be divided into two groups. Group 1 includes schorl, foitite, and pegmatoids feruvite, as well as schorl and foitite of the first generation, tourmaline-muscovite-quartz veinlet in sandstones. Group 2 includes schorl of the second generation, tourmaline-muscovite quartz veinlet, schorl and foitite of quartz-tourmaline metasomatites, and cement dravite of quartz breccia.

Conclusions. Tourmalines of the post-ore mineral associations of the Mnogovershinnoe gold deposit are divided into two groups characterized by different chemical composition and substitutions. Tourmalines of the first group with substitutions Fe $\leftrightarrow \mathrm{Mg}$ and $\mathrm{X}$-vacancy $+\mathrm{Al} \leftrightarrow \mathrm{Na}+\mathrm{R}^{2+}$ are confined to pegmatoids and were formed in reducing or weakly oxidative conditions. Later tourmalines of the second group with substitutions Fe ${ }^{3+} \leftrightarrow \mathrm{Al}$ and $\mathrm{Al}+\mathrm{O}^{2-} \leftrightarrow \mathrm{R}^{2+}+\mathrm{OH}^{-}$indicate a possible porphyry-style mineralization and its formation during lowering oxidative potential.

Keywords: tourmaline, chemical composition, altered rocks, Mnogovershinnoe deposit, Khabarovsk Krai, Far East.

ntroduction

Tourmaline-supergroup minerals with the general formula $\mathrm{XY}_{3} \mathrm{Z}_{6}\left[\mathrm{~T}_{6} \mathrm{O}_{18}\right]\left[\mathrm{BO}_{3}\right]_{3} \mathrm{~V}_{3} \mathrm{~W}$, where $\mathrm{X}=\mathrm{Na}, \mathrm{Ca}, \mathrm{K}, \square$ (vacancy); $\mathrm{Y}=\mathrm{Li}, \mathrm{Mg}, \mathrm{Fe}^{2+}, \mathrm{Mn}^{2+}, \mathrm{Ni}, \mathrm{Al}, \mathrm{Cr}^{3+}, \mathrm{V}^{3+}, \mathrm{Fe}^{3+},\left(\mathrm{Ti}^{4+}\right) ; \mathrm{Z}=\mathrm{Mg}, \mathrm{Fe}^{2+}, \mathrm{Al}^{6}, \mathrm{Fe}^{3+}, \mathrm{V}^{3+}, \mathrm{Cr}^{3+} ; \mathrm{T}=\mathrm{Si}, \mathrm{Al},(\mathrm{B})\left(\mathrm{Fe}^{3+}\right) ; \mathrm{B}=\mathrm{B}, \square ; \mathrm{V}$ $=\mathrm{OH}, \mathrm{O} ; \mathrm{W}=\mathrm{OH}, \mathrm{F}, \mathrm{O}[1]$ are stable in the range from low-temperature hydrothermal conditions to magmatic and high pressured metamorphic conditions. They are characterized by an extraordinary variety of chemical composition and various types of chemical substitutions, which allows us to consider tourmalines as an indicator of mineral formation conditions and an important criterion for prospection and exploration [2-4].

Tourmalines are widespread in some types of gold and gold-polymetallic deposits: porphyry gold (Darasun, Kariyskoye), intrusion related, where they are constitute of barren propylite (Berezovskoye, the middle Urals; Berezitovoe, Transbaikal Krai), hydrothermal-metamorphic or orogenic (Hutti, India; Loulo, Mali; Sigma, Canada). Tourmaline is not typical for igneous gold deposits. However, it is found in some sites where its formation is associated with pre-ore or post-ore processes. This type of deposits includes Mnogovershinnoe in the Khabarovsk Krai, in which the formation of tourmaline is associated with hydrothermal activity due to the intrusion of post-mineral granitoids [5].

Despite the history of half a century for studying the field, information about tourmaline is scarce, and data on the chemical composition are not available. Therefore, the purpose of this study is to characterize the chemical composition of tourmaline to determine its formational identity and the assumption on this basis about the presence of possible new types of mineralization for the deposit.

Brief geology

The Mnogovershinnoe gold deposit is located in the Nikolaevskiy region of the Khabarovsk Krai, $135 \mathrm{~km}$ north of Nikolaevsk-on-Amur and $17 \mathrm{~km}$ from the coast of the Sea of Okhotsk. It was discovered in 1959; the detailed exploration began in 1963, and acquisition - in 1991.

The deposit is a part of the ore field having the same name located at the northern termination of the East Sikhote-Alin volcanic belt at the joint of the Amgunsky and Gorinsky synclinoria of the Sikhote-Alin folded region [6, 7]. The ore field is confined to the Ula volcano-plutonic structure. The ore field is bounded by the Middle Ula and the Kulibinsky latitudinal deep faults from the north and south; the Malakhtinskaya tectonic depression from the northwest; the compound contact of the Bekchi-Ula granitoid pluton from the southeast. The structure of the ore field is two-staged. The lower stage is formed by folded Lower Cretaceous sandstones, mudstones and siltstones. The upper stage is the Paleocene volcanic rocks dominated by vent and subvolcanic facies. The rocks of overlapped facies are almost completely eroded. Volcanic rocks are represented by lavas and tuffs of andesites and andesidacites. Both structural complexes are intruded by the large Bekchi-Ula massif of granitoids, at the northwestern contact of which the Mnogovershinnoye deposit is located. The massif here is the Early Eocene porphyry monzogranodiorites of the first phase. The second intrusive phase is leucocratic and pegmatoid granites. Sandy and clay rocks contacted with the pluton are transformed into hornfelses. In the southwestern part of the ore field, subjacent intrusives of Eocene porphyritic quartz diorite and granodiorite-porphyries were eroded. The volcanic and intrusive rocks are intruded by the Eocene-Oligocene dikes of porphyritic diorite, andesite, basalt, and granite porphyry of north-west and latitudinal strike $[5,8,9]$.

baksheev@geol.msu.ru

https://orcid.org/0000-0001-6920-427X

user420@geol.msu.ru 
The Mnogovershinnoe deposit is divided into two parts separated by the Left Ula NW-trending fault along the Left Ula valley. Gold mineralization is localized in five zones: Glavnaya, Promezhutochnaya, Vodorazdelnaya, Medvezhya and Salali. Economic ore-bodies emerging to the surface are situated exclusively on the right bank, where they are related to the steeply dipping northeastern zones (Tsentralnoe, Verkhnee, Promezhutochnoe, Yuzhnoe, Flangovoe, Severnoe, Tikhoe, Valunistoe, Olenye, Vodorazdelnoe ore bodies). Numerous thin gold-bearing quartz veins of the northwestern and latitudinal strike in sedimentary rocks are known on the left bank (Evatak, Kulibinsky, Konechny, and other sections). The K/Ar age of gold mineralization is 49-69 Ma [10].

Within the ore zones, the contours of economic mineralization are determined by sampling. The length of ore loads along strike is $50-800 \mathrm{~m}$ with a thickness from 0.3 to $7 \mathrm{~m}$. Ore bodies are composed of quartz (95-97\%); the amount of ore minerals is $3-5 \%$. The main ore minerals are pyrite, sphalerite, galena, chalcopyrite; the secondary ones include pyrrhotite, tennantite-tetrahedrite, native gold, electrum, hessite, bornite, acanthite, and marcasite.

Gold (fineness is 750-950) is the main useful component and forms impregnation in quartz and sulphides [5].

Analytical techniques

The backs-scattered electron images (BSE) were obtained using a Jeol JSM-6480 scanning electron microscope equipped with an Inca Energy-350 EDS operated at an accelerating voltage of $15 \mathrm{kV}$ and the current intensity 14-16 nA (analyst N. N. Koshlyakova, Department of Petrology, Moscow State University).

The chemical composition of tourmalines and muscovite was studied using a Jeol JSM-6480 electron microscope equipped with an Inca Energy-350 EDS (analyst N. N. Koshlyakova, Department of Petrology, Moscow State University), operated at accelerating volt-
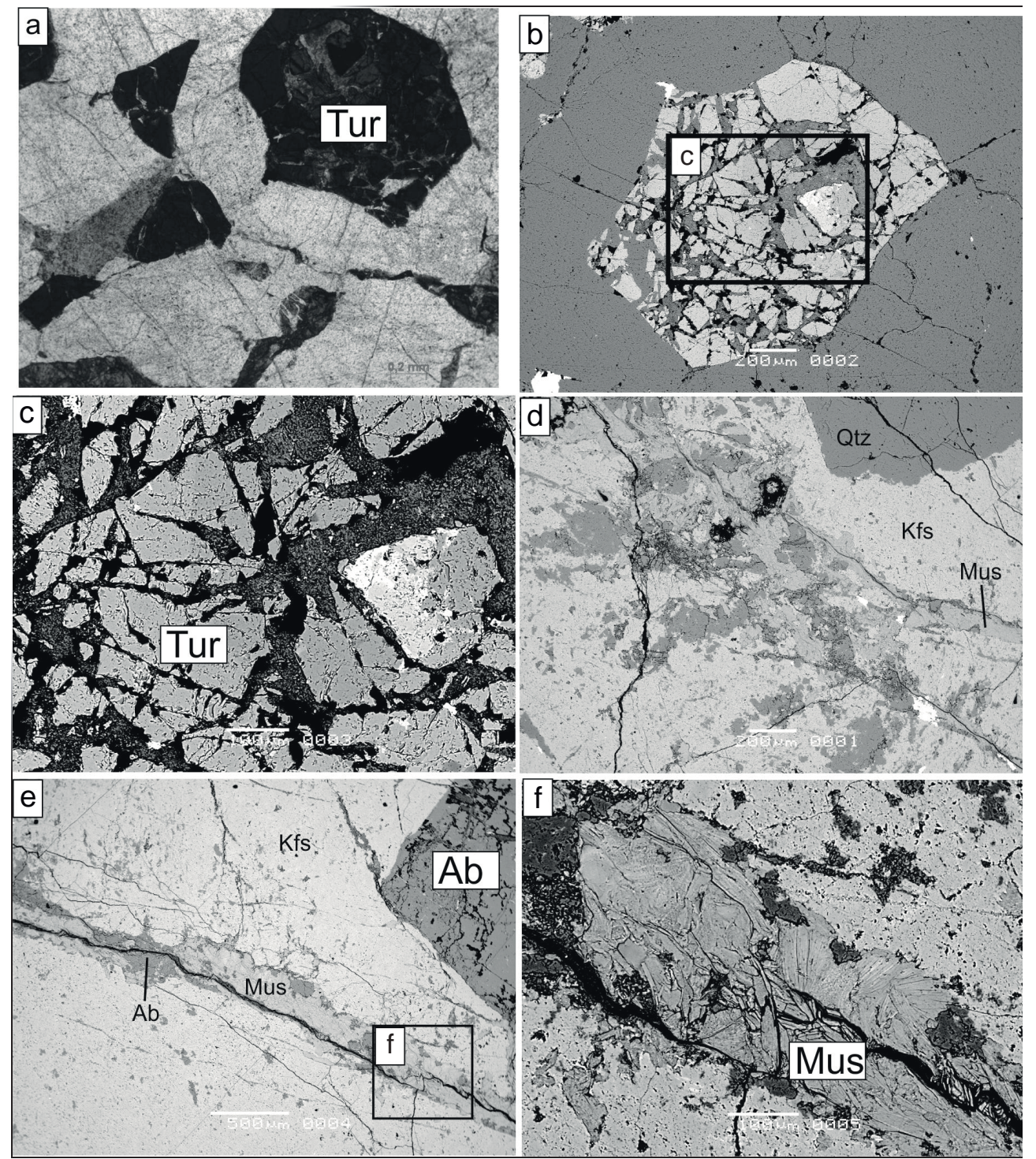

Figure 1. Relationships of pegmatoid minerals of the Zamanchivy site. a-c - brecciated optically zoned schorl crystal, some sectors in the central part of which are enriched potassium feldspar $\mathrm{Ca}$ (to uvite) and depleted in $\mathrm{Na}$ (to foitite), fractures are healed by the albite-muscovite aggregate; $\mathbf{d}$ - albite-muscovite vein in potassium feldspar; $\mathbf{e}$ - intergrowth of albite and potassium feldspar; inclusions of potassium feldspare are observed in albite; $\mathbf{f}$ - enlarged fragment $\mathbf{e}$ showing of muscovite segregations. Sample MN-2. Photo: $\mathbf{a}-$ cross polars, without nicols (b-f) back scattered electrons.

Рисунок 1. Взаимоотношения минералов пегматоидов участка Заманчивый. а-с - брекчированный оптически зональный кристалл шерла, отдельные секторы в центральной части которого обогащены Са (до увита) и обеднены a (до фойтита), трещины залечень альбит-мусковитовым агрегатом; $\mathbf{d}$ - альбит-мусковитовый прожилок в калишпате; e - срастание альбита и калишпата, в альбите отмечаются вростки калишпата; $\mathbf{f}$ - увеличенный фрагмент е, показывающий скопление мусковита. Образец МН-2. Фото. а - в проходящем свете, без николей; b-f - в отраженных электронах. 
Table 1. The average chemical composition (wt. \%) of tourmaline.

Таблица 1. Средний химический состав (мас. \%) турмалина.

\begin{tabular}{|c|c|c|c|c|c|c|}
\hline Comp. & $\mathrm{MN}-2$ & MN-4, generation I & MN-4, generation II & $\mathrm{MN}-7$ & MN-33, generation I & MN-33, generation II \\
\hline $\mathrm{SiO}_{2}$ & $\begin{array}{c}34.65 \\
(32.91-36.89)\end{array}$ & $\begin{array}{c}33.99 \\
(32.36-35.17)\end{array}$ & $\begin{array}{c}34.64 \\
(34.23-35.38)\end{array}$ & $\begin{array}{c}35.75 \\
(35.14-36.18)\end{array}$ & $\begin{array}{c}34.34 \\
(33.73-35.03)\end{array}$ & $\begin{array}{c}33.94 \\
(33.13-34.60)\end{array}$ \\
\hline $\mathrm{TiO}_{2}$ & $\begin{array}{c}0.57 \\
(0.27-1.02)\end{array}$ & $\begin{array}{c}0.86 \\
(0.20-1.15)\end{array}$ & $\begin{array}{c}0.42 \\
(0.21-0.93)\end{array}$ & $\begin{array}{c}0.40 \\
(0.15-0.72)\end{array}$ & $\begin{array}{c}0.56 \\
\text { (bdl -1.33) }\end{array}$ & $\begin{array}{c}0.13 \\
\text { (bdl }-0.26)\end{array}$ \\
\hline $\mathrm{V}_{2} \mathrm{O}_{3}$ & $\begin{array}{c}0.03 \\
\text { (bdl -0.09) }\end{array}$ & bdl & bdl & bdl & $\begin{array}{c}0.03 \\
\text { (bdl }-0.18)\end{array}$ & bdl \\
\hline $\mathrm{Al}_{2} \mathrm{O}_{3}$ & $\begin{array}{c}32.32 \\
(26.40-36.13)\end{array}$ & $\begin{array}{c}35.54 \\
(34.05-37.39)\end{array}$ & $\begin{array}{c}31.27 \\
(30.39-33.83)\end{array}$ & $\begin{array}{c}33.96 \\
(31.45-35.71)\end{array}$ & $\begin{array}{c}29.13 \\
(24.71-33.84)\end{array}$ & $\begin{array}{c}25.95 \\
(20.56-37.78)\end{array}$ \\
\hline $\mathrm{ZnO}$ & $\begin{array}{c}0.04 \\
\text { (bdl }-0.12)\end{array}$ & $\begin{array}{c}0.07 \\
\text { (bdl }-0.17)\end{array}$ & bdl & bdl & bdl & bdl \\
\hline $\mathrm{MnO}$ & $\begin{array}{c}0.21 \\
(0.05-0.50)\end{array}$ & $\begin{array}{c}0.27 \\
(0.21-0.33)\end{array}$ & $\begin{array}{c}0.06 \\
\text { (bdl }-0.11)\end{array}$ & $\begin{array}{c}0.03 \\
\text { (bdl -0,07) }\end{array}$ & $\begin{array}{c}0.02 \\
\text { (b.d.I. }-0.14)\end{array}$ & bdl \\
\hline $\mathrm{FeO}_{\text {gen }}$ & $\begin{array}{c}10.92 \\
(4.68-16.94)\end{array}$ & $\begin{array}{c}10.02 \\
(8.30-12.42)\end{array}$ & $\begin{array}{c}13.86 \\
(11.39-15.87)\end{array}$ & $\begin{array}{c}5.68 \\
(4.47-7.34)\end{array}$ & $\begin{array}{c}13.63 \\
(6.98-19.47)\end{array}$ & $\begin{array}{c}19.18 \\
(12.18-24.07)\end{array}$ \\
\hline $\mathrm{MgO}$ & $\begin{array}{c}4.48 \\
(2.48-8.12)\end{array}$ & $\begin{array}{c}3.06 \\
(1.03-5.17)\end{array}$ & $\begin{array}{c}3.36 \\
(2.58-4.56)\end{array}$ & $\begin{array}{c}7.07 \\
(6.74-7.89)\end{array}$ & $\begin{array}{c}5.06 \\
(3.05-7.17)\end{array}$ & $\begin{array}{c}3.95 \\
(0.75-5.03)\end{array}$ \\
\hline $\mathrm{CaO}$ & $\begin{array}{c}1.25 \\
0.20-3.38\end{array}$ & $\begin{array}{c}0.68 \\
(0.14-0.96)\end{array}$ & $\begin{array}{c}0.58 \\
(0.39-1.13)\end{array}$ & $\begin{array}{c}0.74 \\
(0.42-1.26)\end{array}$ & $\begin{array}{c}1.31 \\
0.58-1.98\end{array}$ & $\begin{array}{c}0.96 \\
(0.40-81.54)\end{array}$ \\
\hline $\mathrm{K}_{2} \mathrm{O}$ & $\begin{array}{c}0.02 \\
\text { (bdl -0.09) }\end{array}$ & $\begin{array}{c}0.04 \\
\text { (bdl }-0,07)\end{array}$ & bdl & $\begin{array}{c}0.05 \\
(0.03-0.07)\end{array}$ & $\begin{array}{c}0.03 \\
\text { (bdl }-0,07)\end{array}$ & $\begin{array}{c}0.05 \\
\text { (bdl -0.09) }\end{array}$ \\
\hline $\mathrm{Na}_{2} \mathrm{O}$ & $\begin{array}{c}1.54 \\
(0.96-2.59)\end{array}$ & $\begin{array}{c}1.46 \\
(1.23-1.67)\end{array}$ & $\begin{array}{c}1.83 \\
(1.48-2.11)\end{array}$ & $\begin{array}{c}1.89 \\
(1.69-2.20)\end{array}$ & $\begin{array}{c}1.90 \\
(1.49-2.44)\end{array}$ & $\begin{array}{c}2.02 \\
(1.08-2.49)\end{array}$ \\
\hline $\mathrm{B}_{2} \mathrm{O}_{3}$ & $\begin{array}{c}10.34 \\
(9.93-10.74)\end{array}$ & $\begin{array}{c}10.40 \\
(10.24-10.55)\end{array}$ & $\begin{array}{c}10.25 \\
(10.13-10.48)\end{array}$ & $\begin{array}{c}10.59 \\
(10.38-10.71)\end{array}$ & $\begin{array}{c}10.21 \\
(9.98-10.54)\end{array}$ & $\begin{array}{c}10.03 \\
(9.89-10.31)\end{array}$ \\
\hline $\mathrm{H}_{2} \mathrm{O}$ & $\begin{array}{c}3.42 \\
(3.15-3.53)\end{array}$ & $\begin{array}{c}3.31 \\
(3.24-3.39)\end{array}$ & $\begin{array}{c}3.53 \\
(3.49-3.60)\end{array}$ & $\begin{array}{c}3.41 \\
(3.27-3.49)\end{array}$ & $\begin{array}{c}2.64 \\
(3.44-3.63)\end{array}$ & $\begin{array}{c}3.46 \\
(3.21-3.51)\end{array}$ \\
\hline Total & $\begin{array}{c}99.78 \\
(98.12- \\
100.59)\end{array}$ & $\begin{array}{c}99.70 \\
(98.69-100.23)\end{array}$ & $\begin{array}{c}99.81 \\
(99.43-100.47)\end{array}$ & $\begin{array}{c}99.56 \\
(98.63-100.08)\end{array}$ & $\begin{array}{c}98.85 \\
(98.42-100.32)\end{array}$ & $\begin{array}{c}99.67 \\
(99.29-99.86)\end{array}$ \\
\hline \multicolumn{7}{|c|}{ Formula based on 15 cations } \\
\hline Si & $\begin{array}{c}5.826 \\
(5.696-5.972)\end{array}$ & $\begin{array}{c}5.680 \\
(5.471-5.794)\end{array}$ & $\begin{array}{c}5.873 \\
(5.868-5.881)\end{array}$ & $\begin{array}{c}5.867 \\
(5.844-5.891)\end{array}$ & $\begin{array}{c}5.848 \\
(5.674-5.903)\end{array}$ & $\begin{array}{c}5.880 \\
(5.585-5.987)\end{array}$ \\
\hline${ }^{\mathrm{T}} \mathrm{Al}$ & $\begin{array}{c}0.174 \\
(0.028-0.304)\end{array}$ & $\begin{array}{c}0.320 \\
(0.206-0.529)\end{array}$ & $\begin{array}{c}0.127 \\
(0.119-0.132)\end{array}$ & $\begin{array}{c}0.133 \\
(0.109-0.156)\end{array}$ & $\begin{array}{c}0.152 \\
(0.097-0.326)\end{array}$ & $\begin{array}{c}0.120 \\
(0.013-0.415)\end{array}$ \\
\hline$\Sigma T$ & 6.000 & 6.000 & 6.000 & 6.000 & 6.000 & 6.000 \\
\hline${ }^{\mathrm{z}} \mathrm{Al}$ & $\begin{array}{c}6.000 \\
(5.162-6.000)\end{array}$ & 6.000 & $\begin{array}{c}6.000 \\
(5.944-6.000)\end{array}$ & 6.000 & $\begin{array}{c}5.694 \\
(4.924-6.000)\end{array}$ & $\begin{array}{c}5.180 \\
(4.218-6.000)\end{array}$ \\
\hline $\mathrm{z} \mathrm{Mg}$ & $0(0-0.838)$ & - & $0(0-0.056)$ & - & $\begin{array}{c}0.306 \\
(0-1.076)\end{array}$ & $\begin{array}{c}0.820 \\
(0-1.311)\end{array}$ \\
\hline${ }^{\mathrm{z}} \mathrm{Fe}^{3+}$ & - & - & - & - & - & $0(0-0.531)$ \\
\hline$\Sigma Z$ & 6.000 & 6.000 & 6.000 & 6.000 & 6.000 & 6.000 \\
\hline ҮMg & $\begin{array}{c}1.121 \\
(0.539-1.974)\end{array}$ & $\begin{array}{c}0.762 \\
(0.260-1.275)\end{array}$ & $\begin{array}{c}0.849 \\
(0-1.098)\end{array}$ & $\begin{array}{c}1.730 \\
(1.635-1.934)\end{array}$ & $\begin{array}{c}0.980 \\
(0.045-1.751)\end{array}$ & $\begin{array}{c}0.202 \\
(0-0.777)\end{array}$ \\
\hline $\mathrm{Fe}^{2+}$ & $\begin{array}{c}1.536 \\
(0.634-2.251)\end{array}$ & $\begin{array}{c}1.402 \\
(1.150-1.765)\end{array}$ & $\begin{array}{c}1.882 \\
(1.581-2.089)\end{array}$ & $\begin{array}{c}0.780 \\
(0.606-1.028)\end{array}$ & $\begin{array}{c}1.744 \\
(0.964-2.344)\end{array}$ & $\begin{array}{c}1.920 \\
(1.719-2.153)\end{array}$ \\
\hline${ }^{\mathrm{Y}} \mathrm{Al}$ & $\begin{array}{c}0.232 \\
(0-0.854)\end{array}$ & $\begin{array}{c}0.681 \\
(0.401-1.057)\end{array}$ & $\begin{array}{c}0.122 \\
(0-0.481)\end{array}$ & $\begin{array}{c}0.437 \\
(0.088-0.701)\end{array}$ & $\begin{array}{c}0 \\
(0-0.301)\end{array}$ & $\begin{array}{c}0 \\
(0-1.093)\end{array}$ \\
\hline${ }^{Y} \mathrm{Fe}^{3+}$ & $\begin{array}{c}0 \\
(0-0.268)\end{array}$ & - & $\begin{array}{c}0.084 \\
(0-0.194)\end{array}$ & - & $\begin{array}{c}0.198 \\
(0-0.556)\end{array}$ & $\begin{array}{c}0.861 \\
(0-1.783)\end{array}$ \\
\hline $\mathrm{Ti}$ & $\begin{array}{c}0.072 \\
(0.033-0.131)\end{array}$ & $\begin{array}{c}0.109 \\
(0.025-0.146)\end{array}$ & $\begin{array}{c}0.054 \\
(0.027-0.118)\end{array}$ & $\begin{array}{c}0.050 \\
(0.018-0.091)\end{array}$ & $\begin{array}{c}0.071 \\
(0-0.173)\end{array}$ & $\begin{array}{c}0.017 \\
(0-0.034)\end{array}$ \\
\hline V & $\begin{array}{c}0.004 \\
(0-0.013)\end{array}$ & - & - & - & $\begin{array}{c}0.004 \\
(0-0.024)\end{array}$ & - \\
\hline $\mathrm{Zn}$ & $\begin{array}{c}0.005 \\
(0-0.015)\end{array}$ & $\begin{array}{c}0.008 \\
(0-0.021)\end{array}$ & - & - & - & - \\
\hline $\mathrm{Mn}$ & $\begin{array}{c}0.030 \\
(0.007-0.074)\end{array}$ & $\begin{array}{c}0.038 \\
(0.030-0.048)\end{array}$ & $\begin{array}{c}0.009 \\
(0.000-0.016)\end{array}$ & $\begin{array}{c}0.004 \\
(0.000-0.009)\end{array}$ & $\begin{array}{c}0.002 \\
(0.000-0.019)\end{array}$ & - \\
\hline$\Sigma Y$ & 3.000 & 3.000 & 3.000 & 3.000 & 3.000 & 3.000 \\
\hline $\mathrm{Na}$ & $\begin{array}{c}0.502 \\
(0.315-0.814)\end{array}$ & $\begin{array}{c}0.475 \\
(0.394-0.539)\end{array}$ & $\begin{array}{c}0.603 \\
(0.475-0.702)\end{array}$ & $\begin{array}{c}0.601 \\
(0.548-0.694)\end{array}$ & $\begin{array}{c}0.628 \\
(0.475-0.782)\end{array}$ & $\begin{array}{c}0.678 \\
(0.353-0.848)\end{array}$ \\
\hline X-vac. & $\begin{array}{c}0.272 \\
(0.069-0.499)\end{array}$ & $\begin{array}{c}0.404 \\
(0.289-0.580)\end{array}$ & $\begin{array}{c}0.292 \\
(0.227-0.454)\end{array}$ & $\begin{array}{c}0.269 \\
(0.215-0.322)\end{array}$ & $\begin{array}{c}0.132 \\
(0.079-0.260)\end{array}$ & $\begin{array}{c}0.144 \\
(0.048-0.470)\end{array}$ \\
\hline $\mathrm{Ca}$ & $\begin{array}{c}0.225 \\
(0.035-0.616)\end{array}$ & $\begin{array}{c}0.122 \\
(0.026-0.172)\end{array}$ & $\begin{array}{c}0.106 \\
(0.071-0.205)\end{array}$ & $\begin{array}{c}0.130 \\
(0.073-0.223)\end{array}$ & $\begin{array}{c}0.240 \\
(0.102-0.365)\end{array}$ & $\begin{array}{c}0.178 \\
(0.090-0.288)\end{array}$ \\
\hline
\end{tabular}




\begin{tabular}{|c|c|c|c|c|c|c|}
\hline Comp. & $\mathrm{MN}-2$ & MN-4, generation I & MN-4, generation II & $\mathrm{MN}-7$ & MN-33, generation I & MN-33, generation II \\
\hline $\mathrm{K}$ & $\begin{array}{c}0.005 \\
(0-0.019)\end{array}$ & $\begin{array}{c}0.008 \\
(0.000-0.014)\end{array}$ & - & - & $\begin{array}{c}0.006 \\
(0-0.015)\end{array}$ & $\begin{array}{c}0.010 \\
(0-0.020)\end{array}$ \\
\hline$\Sigma \mathrm{X}$ & 1.000 & 1.000 & 1.000 & 1.000 & 1.000 & 1.000 \\
\hline${ }^{\mathrm{v}} \mathrm{OH}^{-}$ & 3.000 & 3.000 & 3.000 & 3.000 & 3.000 & 3.000 \\
\hline${ }^{\mathrm{w}} \mathrm{OH}^{-}$ & $\begin{array}{c}0.837 \\
(0.591-1.000)\end{array}$ & $\begin{array}{c}0.695 \\
(0.653-0.749)\end{array}$ & $\begin{array}{c}1.000 \\
(0.979-1.000)\end{array}$ & $\begin{array}{c}0.737 \\
(0.543-0.878)\end{array}$ & $\begin{array}{c}1.000 \\
(0.914-1.000)\end{array}$ & $\begin{array}{c}1.000 \\
(0.616-1.000)\end{array}$ \\
\hline${ }^{\mathrm{w}} \mathrm{O}^{2-}$ & $\begin{array}{c}0.163 \\
(0-0.409)\end{array}$ & $\begin{array}{c}0.305 \\
(0.251-0.347)\end{array}$ & $\begin{array}{c}0 \\
(0-0.021)\end{array}$ & - & $\begin{array}{c}0 \\
(0.042-0.086)\end{array}$ & $\begin{array}{c}0 \\
(0-0.384)\end{array}$ \\
\hline $\mathrm{Fe}_{\text {tot }}$ & $\begin{array}{c}1.536 \\
(0,634-2,482)\end{array}$ & $\begin{array}{c}1.402 \\
(1.150-1.765)\end{array}$ & $\begin{array}{c}1.966 \\
(1.581-2.275)\end{array}$ & $\begin{array}{c}0.780 \\
(0.606-1.028)\end{array}$ & $\begin{array}{c}1.942 \\
(0.964-2.837)\end{array}$ & $\begin{array}{c}2.781 \\
(1.719-3.531)\end{array}$ \\
\hline $\mathrm{Mg}_{\text {tot }}$ & $\begin{array}{c}1.122 \\
(0.616-1.974)\end{array}$ & $\begin{array}{c}0.762 \\
(0.260-1.275)\end{array}$ & $\begin{array}{c}0.849 \\
(0.659-1.154)\end{array}$ & $\begin{array}{c}1.730 \\
(1.635-1.934)\end{array}$ & $\begin{array}{c}1.286 \\
(0.772-1.766)\end{array}$ & $\begin{array}{c}1.021 \\
(0.188-1.311)\end{array}$ \\
\hline $\mathrm{Al}_{\mathrm{tot}}$ & $\begin{array}{c}6.405 \\
(5.285-7.041)\end{array}$ & $\begin{array}{c}7.001 \\
(6.641-7.343)\end{array}$ & $\begin{array}{c}6.249 \\
(6.074-6.613)\end{array}$ & $\begin{array}{c}6.570 \\
(6.205-6.845)\end{array}$ & $\begin{array}{c}5.847 \\
(5.054-6.580)\end{array}$ & $\begin{array}{c}5.300 \\
(4.250-7.508)\end{array}$ \\
\hline fe & $\begin{array}{c}0.58 \\
(0.24-0.75)\end{array}$ & $\begin{array}{c}0.65 \\
(0.47-0.87)\end{array}$ & $\begin{array}{c}0.70 \\
(0.60-0.78)\end{array}$ & $\begin{array}{c}0.31 \\
(0.27-0.37)\end{array}$ & $\begin{array}{c}0.60 \\
(0.36-0.77)\end{array}$ & $\begin{array}{c}0.73 \\
(0.63-0.90)\end{array}$ \\
\hline ca & $\begin{array}{c}0.31 \\
(0.04-0.66)\end{array}$ & $\begin{array}{c}0.20 \\
(0.06-0.25)\end{array}$ & $\begin{array}{c}0.15 \\
(0.09-0.27)\end{array}$ & $\begin{array}{c}0.18 \\
(0.10-0.29)\end{array}$ & $\begin{array}{c}0.28 \\
(0.12-0.41)\end{array}$ & $\begin{array}{c}0.21 \\
(0.10-0.33)\end{array}$ \\
\hline vac & $\begin{array}{c}0.35 \\
(0.16-0.52)\end{array}$ & $\begin{array}{c}0.46 \\
(0.35-0.60)\end{array}$ & $\begin{array}{c}0.33 \\
(0.24-0.49)\end{array}$ & $\begin{array}{c}0.31 \\
(0.25-0.37)\end{array}$ & $\begin{array}{c}0.17 \\
(0.12-0.32)\end{array}$ & $\begin{array}{c}0.17 \\
(0.07-0.57)\end{array}$ \\
\hline
\end{tabular}

Note: bdl - below detection limits by the electron micrpoprobe. $f e=\mathrm{Fe} /(\mathrm{Fe}+\mathrm{Mg}), \mathrm{ca}=\mathrm{Ca} /(\mathrm{Ca}+\mathrm{Na}), \mathrm{vac}=\mathrm{X}$-vacancy $/(\mathrm{X}$-vacancy $+\mathrm{Na})$. The range of content is given in parentheses.

Примечание: bdl (н.п.о.) - ниже предела обнаружения электронно-зондовым методом; fe $=\mathrm{Fe} /(\mathrm{Fe}+\mathrm{Mg}), \mathrm{ca}=\mathrm{Ca} /(\mathrm{Ca}+\mathrm{Na}), \mathrm{vac}=$ X-вакансия/(X-вакансия + Na). В скобках приведены пределы содержания.

age $15 \mathrm{kV}$, current intensity $30 \pm 0.1 \mathrm{nA}$. XPP corrections were used for the correction procedure (INCA program, version 17a). The profile lines of characteristic X radiation are optimized and normalized using natural silicate standards [11].

Tourmalines formulas were calculated on the basis 15 cations, excluding $\mathrm{Na}$, $\mathrm{Ca}$, and $\mathrm{K}$, which implies the absence of vacancies at tetrahedral and octahedral sites and a small amount of $\mathrm{Li}$ [12]. The amounts of $\mathrm{OH}^{-}$and $\mathrm{O}^{2}$ - at sites $V$ and $W$ are estimated from the charge balance constraints. It is assumed that oxygen ions $\mathrm{O}^{2-}$ preferably occupies position $W$ along with $\mathrm{F}^{-}$ions [1]. The vacancy rate $(\square)$ in the $X$ position is calculated by the stoichiometric ratio based on the equation $1=\mathrm{Na}+\mathrm{Ca}+\mathrm{K}+\square$. The $\mathrm{B}_{2} \mathrm{O}_{3}$ content is also calculated by stoichiometry. The muscovite formula is calculated for 22 negative charges.

Results

Samples of tourmaline were selected within prospecting sites of Zamanchivy (sam. MN-2, MN-4, MN-7) located in the continuation of the ore body Valunistoe and Kulibinsky (MN-33). The sites are situated in the eastern and western flanks of the ore field, respectively. Samples were taken from pit bings and rock outcrops.

Tourmaline-bearing formations of the Zamanchivy site are pegmatoids with tourmaline bunches (MN-2), tourmaline-muscovite-quartz veinlets in hydrothermally altered sandstones (MN-4), and quartz breccia with tourmaline cement (MN-7).

Pegmatoids (sample MN-2) are massive large-crystalline muscovite-quartz-feldspar rocks with tourmaline bunches. The size of the last ones is $2-5 \mathrm{~mm}$.

Tourmaline assemblages interstices between quartz grains and cracks in them and forms relatively large crystals of up to several $\mathrm{mm}$ in size (Fig. 1a). It is pleochroic; from light mossy or mossy to dark mossy color. Optical zoning is very weak. Tourmaline crystals are sometimes brecciated and exhibit complex zoning in chemical composition. Rare sectors in the central part of such crystals are enriched in $\mathrm{Ca}(0.44-0.62 \mathrm{apfu})$ and $\mathrm{Fe}$ (1.75-2.48 apfu) (Fig. 1b, c). In addition, calculations show that the content of $\mathrm{Fe}^{3+}$ in them is $0.23-0.27$ apfu. Other sectors in the central part of crystals have a lower Ca content (0.05-0.16 apfu) and contain less Fe (1.45-1.54 apfu).

The crystal rims have a composition close to the low-calcium sectors in the central part differing slightly in Fe content (1.70 apfu). It is impossible to calculate $\mathrm{Fe}^{3+}$ concentration in them and in low-calcium sectors. A special feature of tourmaline is a fairly high $\mathrm{Zn}$ (up to $0.12 \mathrm{wt} . \% \mathrm{ZnO}$ ); there are other impurities such as $\mathrm{Mn}$ (up to $0.50 \mathrm{wt} . \% \mathrm{MnO}$ ) and $\mathrm{Ti}$ (up to $1.0 \mathrm{wt} . \% \mathrm{TiO}_{2}$ ) $(\mathrm{Table} 1$ ).

In the triangular diagram in terms of X-vacancy $-\mathrm{Ca}-\mathrm{Na}(+\mathrm{K})$ (Fig. 2a), the tourmaline compositions fall into all three fields; taking into account $\mathrm{Fe}$ and $\mathrm{Mg}$ contents, it makes it possible to attribute these compositions to feruvite, schorl and foitite. On the other hand, the determination of the content of ferric iron can change classification.

The charge ${ }^{1}$ versus $\mathrm{Mg}+\mathrm{Fe}+{ }^{\mathrm{x}} \square$ plot (Fig. 2c) shows that $\mathrm{Fe}^{3+} \leftrightarrow \mathrm{Al}$ substitution is exhibited in feruvite, while $\mathrm{Al}+\mathrm{O}^{2-} \leftrightarrow$ $\mathrm{R}+\mathrm{OH}$ in schorl and foitite, where $\mathrm{R}=\mathrm{Fe}^{2+} \mathrm{Mg}$. In the diagram in coordinates (X-vacancy $-\mathrm{Al}$ coordinates (Fig. 2e)), imaging points of feruvite compositions are located along the vector $\mathrm{FeAl}_{-1}$, and the composition points of the schorl and foitite are almost parallel to the vector $\square \mathrm{Al}(\mathrm{NaR})_{-1}\left(\mathrm{R}=\mathrm{Fe}^{2+}, \mathrm{Mg}\right)$, corresponding to substitutions $\mathrm{Fe}^{3+} \leftrightarrow \mathrm{Al}$ and ${ }^{\mathrm{X}} \square+\mathrm{Al} \leftrightarrow \mathrm{Na}+\mathrm{R}^{2+}$, respectively.

White mica together with albite builds up intersecting veinlets up to several hundred microns in thickness in potassium feldspar (Fig. 1d-e). Chemically, mica refers to muscovite (Table 2, 1-4). The Fe and $\mathrm{Mg}$ contents range from 0.16 to 0.25 a.f. and from 0.07 to $0.12 \mathrm{apfu}$, respectively. It can be seen from these data that the described mica differs from muscovite from sample MN-4 by a significantly higher Fe concentration and a slightly lower Mg grade. Muscovite from sample MN-2 does not contain F. 

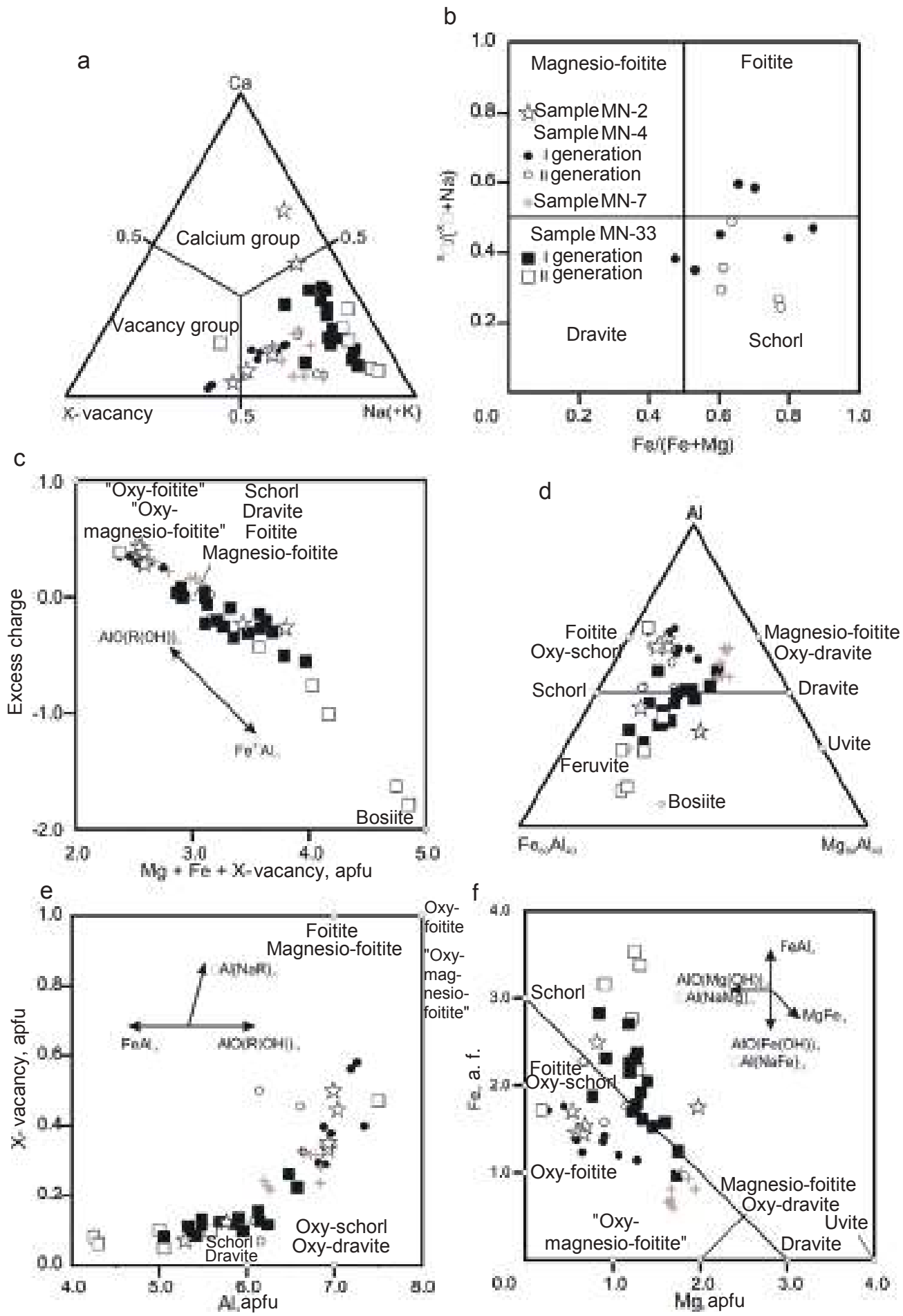

Figure 2. Triangular (a, d) and binary (b, c, e) diagrams showing compositions from the Zamanchivy and Kulibinsky sites of Mnogovershinny ore field, Khabarovsk Krai. (a) X-vacancy - Ca-Na (+ K), (b) Fe $e_{\text {total }} /\left(\mathrm{Fe}_{\text {total }}+\mathrm{Mg}\right)-\mathrm{X}$-vacancy/(X-vacancy $\left.+\mathrm{Na}\right),(\mathrm{c}) \mathrm{Mg}+\mathrm{Fe}+\mathrm{X}-\mathrm{va}-$ cancy - excess charge, (d) Fe-Al-Mg, (e) Al-X-vacancy, (f) Mg-Fe.

Рисунок 2. Треугольные (a, г) и бинарные (б, в, д) диаграммы, иллюстрирующие составы турмалинов участков Заманчивый и

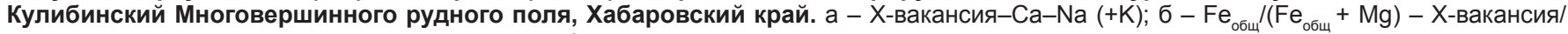
(Х-вакансия + Na); в - Mg + Fe + X-вакансия - избыточный заряд; г - Fe-Al-Mg; д - Al-X-вакансия; e - Mg-Fe.

Tourmaline-muscovite-quartz veinlet in hydrothermally altered sandstones (sam. MN-4).

Tourmaline occurs as relatively large crystals with a thickness of $1-5 \mathrm{~mm}$ and a length of up to $12 \mathrm{~mm}$, the fractures in which are healed with later tourmaline (Fig. 3a-c). The crystals are pleochroic from light orange to dark orange. The BSE images of such crystals show slightly osscillatory zoning (Fig. 3c, d) due to variable Fe and Mg contents (Fig. 1a, b, d; Table 1). Chemically, large crystals belong to the vacancy and alkali series (Fig. 2a). The Fe/(Fe $+M g$ ) versus ${ }^{\mathrm{X}} \square /(\mathrm{X} \square+\mathrm{Na}$ ) diagram (Fig. 2b) shows that tourmalines are classified as foitite and schorl; just one composition - to dravite. The relationship between schorl and foitite is unclear. Foitite is characterized by its $\mathrm{Fe} /(\mathrm{Fe}+\mathrm{Mg})$ value $0.65-0.70$; it contains $0.02-0.04$ apfu Ti; Ca concentration is $0.03-0.04$ apfu. The $\mathrm{Fe} /(\mathrm{Fe}+\mathrm{Mg})$ value of schorl varies from 0.53 to 0.86 . 

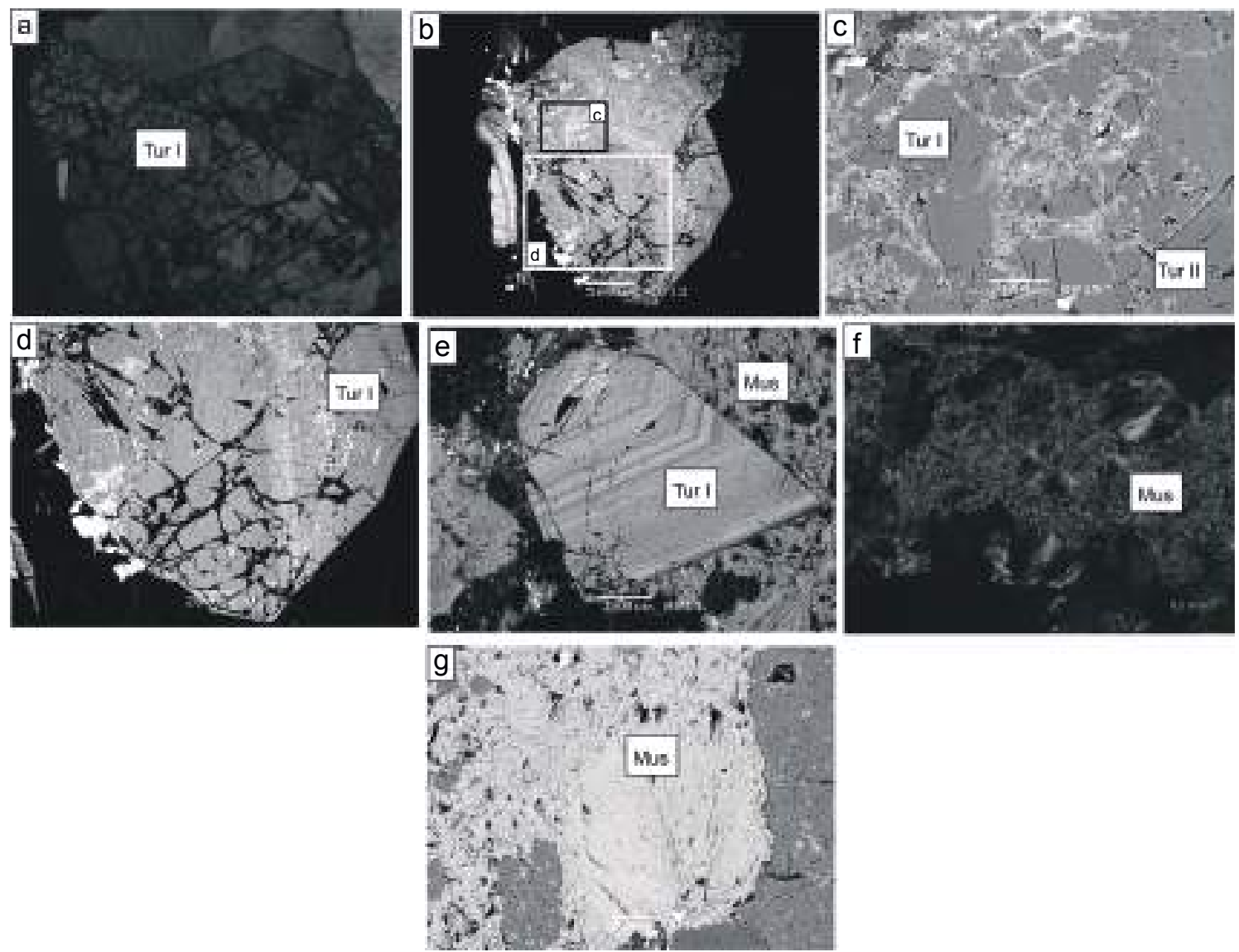

Figure 3. Large tourmaline crystals and muscovite separation. a - early tourmaline; $\mathbf{b}$ - view of foitite crystal; $\mathbf{c}$ - scaled-up fragment b showing that the crystal in the cracks is replaced by a later, more ferrous tourmaline; $\mathbf{d}$ - scaled-up fragment $\mathbf{b}$; $\mathbf{e}$ - early schorl crystal with rhythmic zonality; e, $\mathbf{g}$ - muscovite separation. The Zamanchivy site, MN-4 sample. Photo: $\mathbf{a}, \mathbf{f}-$ in the incident light, nicols are crossed, $\mathbf{b}-\mathbf{e}, \mathbf{g}-$ in back scattered electrons.

Рисунок 3. Крупные кристаллы турмалина и выделения мусковита. $\mathbf{a}$ - ранний турмалин; $\mathbf{b}$ - общий вид кристалла фойтита; $\mathbf{c}-$ увеличенный фрагмент $\mathbf{b}$, показывающий, что кристалл по трещинам замещается поздним, более железистым турмалином; $\mathbf{d}-$ увеличенный фрагмент $\mathbf{b} ; \mathbf{e}-$ кристалл раннего шерла с ритмичной зональностью; $\mathbf{e}, \mathbf{g}$ - выделения мусковита. Участок Заманчивый, образец МH-4. Фото. a, f - в проходящем свете, николи скрещены, b-e, $\mathbf{g}$ - в отраженных электронах.

Similar to pegmatoids, the described schorl is enriched in $\mathrm{Zn}$ (up to $0.17 \mathrm{wt} . \% \mathrm{ZnO}$ ). The Mn concentration (up to $0.33 \mathrm{wt} . \%$ $\mathrm{MnO}$ ) and $\mathrm{Ti}$ (up to $1.2 \mathrm{wt} \% \mathrm{TiO}_{2}$ ) in schorl and foitite (Table 1 ) is also comparable. The calculated formulas of foitite and veinlet schorl turned out to be balanced in charge; therefore, it is impossible to estimate $\mathrm{Fe}^{3+}$ content in these minerals using calculations.

Blue-green tourmaline, which heals the fractures, can be considered as a second-generation tourmaline. Alongside, quartz and carbonate are found in the cracks. Chemically, tourmaline falls into the alkali field (Fig. 2a). The diagram (Fig. 2b) shows that the mineral is classified as schorl. Its iron content varies from 0.60 to 0.78 ; it contains $0.03-0.12$ apfu Ti and $0.07-0.21 \mathrm{apfu}$. Ca (Table 1). Calculations indicate that tourmaline II is enriched in $\mathrm{Fe}^{3+}$ (up to 0.19 a.f.) compared with earlier schorl and foitite. This may indicate more oxiditive conditions of its formation.

The plot excess charge versus $\mathrm{Mg}+\mathrm{Fe}+{ }^{\mathrm{X}} \square$ (Fig. 2c) indicates substitution $\mathrm{Al}+\mathrm{O}^{2-} \leftrightarrow \mathrm{R}+\mathrm{OH}^{-}\left(\mathrm{R}=\mathrm{Fe}^{2+}, \mathrm{Mg}\right)$ in the early schorl and foitite whereas late schorl demonstrates $\mathrm{Fe}^{3+} \leftrightarrow \mathrm{Al}$ substitution.

For early tourmaline, a significant negative correlation was established between the pairs of $\mathrm{NaMg}$ and $\mathrm{x} \square \mathrm{Al}(\mathrm{r}=-0.84)$ and between $\mathrm{Fe}$ and $\mathrm{Mg}(\mathrm{r}=-0.82)$. This fact shows that the leading types of substitutions in the early schorl and foitite are ${ }^{\mathrm{x}} \mathrm{Na}+\mathrm{Mg}$ $\leftrightarrow{ }^{\mathrm{X}} \square+\mathrm{Al}$ and $\mathrm{Fe} \mathrm{Mg}$ with the minor substitution $\mathrm{Al}+\mathrm{O}^{2-} \leftrightarrow \mathrm{R}+\mathrm{OH}^{-}$, which is reflected in the diagrams shown in Fig. 2e, f.

White mica composes colorless separations of two types differing in size: rosettes with a diameter up to several tenths of $\mathrm{mm}$ and small scales which rosettes are coated with (Fig. 3f, g) and replace primary plagioclase and potassium feldspar. Chemically, mica refers to muscovite (Table 2, an. 5-8). The Fe and Mg concentrations range from 0.07 to 0.09 apfu and from 0.10 to 0.15 apfu, respectively. Muscovite does not contain F.

Breccia with muscovite-tourmaline cement (sam. MN-7). The rock is composed of fragments of vein quartz, which are cemented by tourmaline and a small amount of white mica. The size of fragments of quartz is up to several $\mathrm{cm}$.

Tourmaline is represented by small crystals of several dozens of microns (Fig. 4), which are pleochroic from light green to green. The BSE images show that the crystals are weakly zoned (Fig. 4a). The content of Fe in the mineral is low (0.61-1.03 apfu); Ca content is also low (0.07-0.21 apfu). Tourmaline contains minor Mn (up to $0.01 \mathrm{apfu}$ ); Ti concentration ranges from 0.02 to $0.09 \mathrm{apfu}$ (Table 1). In the triangular diagram in terms of X-vacancy - Ca-Na (+ K) (Fig. 2a), the compositions fall in the alkali field; together with the results of calculation of the formulas, it makes it possible to refer the described tourmaline to dravite. The calculated formulas of dravite turned out to be balanced in charge; therefore, it is impossible to estimate $\mathrm{Fe}^{3+}$ content in the mineral by means of calculations. 
Table 2. Chemical composition of muscovite (in wt.\%) of the rocks of the Mnogovershinnoe ore deposit.

Таблица 2. Химический состав мусковита (в мас. \%) пород Многовершинного рудного поля.

\begin{tabular}{|c|c|c|c|c|c|c|c|c|c|c|}
\hline No & 1 & 2 & 3 & 4 & 5 & 6 & 7 & 8 & 9 & 10 \\
\hline $\mathrm{SiO}_{2}$ & 47.76 & 48.00 & 46.28 & 46.75 & 47.75 & 47.25 & 48.16 & 46.47 & 46.59 & 47.25 \\
\hline $\mathrm{TiO}_{2}$ & bdl & bdl & 0.22 & 0.13 & bdl & 0.12 & bdl & bdl & 0.44 & 0.13 \\
\hline $\mathrm{V}_{2} \mathrm{O}_{3}$ & bdl & 0.08 & bdl & bdl & bdl & bdl & bdl & bdl & bdl & bdl \\
\hline $\mathrm{Al}_{2} \mathrm{O}_{3}$ & 35.37 & 34.92 & 32.11 & 33.16 & 35.77 & 36.06 & 35.59 & 36.92 & 37.21 & 36.64 \\
\hline $\mathrm{MnO}$ & bdl & bdl & 0.06 & I.d.I. & bdl & 0.10 & bdl & bdl & bdl & bdl \\
\hline $\mathrm{FeO}_{\text {gen }}$ & 3.16 & 2.99 & 4.34 & 3.27 & 1.46 & 1.64 & 1.34 & 1.27 & 2.10 & 3.41 \\
\hline $\mathrm{MgO}$ & 0.70 & 0.76 & 1.14 & 0.99 & 1.36 & 1.58 & 1.39 & 0.98 & 0.95 & 0.56 \\
\hline $\mathrm{CaO}$ & bdl & bdl & bdl & bdl & bdl & I.d.I. & 0.07 & bdl & 0.05 & 0.20 \\
\hline $\mathrm{K}_{2} \mathrm{O}$ & 10.63 & 10.62 & 10.78 & 10.48 & 10.43 & 10.56 & 10.49 & 10.82 & 11.31 & 9.94 \\
\hline $\mathrm{Na}_{2} \mathrm{O}$ & 0.20 & 0.21 & 0.24 & 0.14 & 0.19 & 0.33 & 0.21 & 0.22 & 0.32 & bdl \\
\hline $\mathrm{H}_{2} \mathrm{O}$ & 4.59 & 4.59 & 4.42 & 4.45 & 4.60 & 4.61 & 4.61 & 4.57 & 4.64 & 4.62 \\
\hline Total & 102.41 & 102.17 & 99.59 & 99.37 & 101.56 & 102.25 & 101.86 & 101.25 & 103.69 & 102.75 \\
\hline \multicolumn{11}{|c|}{ The formula is calculated for 22 negative charges } \\
\hline $\mathrm{Si}$ & 3.114 & 3.134 & 3.139 & 3.148 & 3.111 & 3.070 & 3.126 & 3.045 & 3.007 & 3.060 \\
\hline${ }^{\mathrm{T}} \mathrm{Al}$ & 0.886 & 0.866 & 0.861 & 0.852 & 0.889 & 0.930 & 0.874 & 0.955 & 0.993 & 0.940 \\
\hline${ }^{\circ} \mathrm{Al}$ & 1.858 & 1.831 & 1.850 & 1.897 & 1.832 & 1.822 & 1.707 & 1.780 & 1.858 & 1.839 \\
\hline $\mathrm{Mg}$ & 0.068 & 0.074 & 0.115 & 0.099 & 0.132 & 0.153 & 0.135 & 0.096 & 0.091 & 0.054 \\
\hline $\mathrm{Ti}$ & 0.000 & - & 0.011 & 0.007 & - & 0.006 & - & - & 0.021 & 0.006 \\
\hline $\mathrm{Fe}$ & 0.172 & 0.163 & 0.246 & 0.184 & 0.080 & 0.089 & 0.073 & 0.070 & 0.113 & 0.185 \\
\hline V & - & 0.004 & - & - & - & - & - & - & - & - \\
\hline $\mathrm{Mn}$ & - & - & 0.003 & - & - & 0.006 & - & - & - & - \\
\hline $\mathrm{K}$ & 0.884 & 0.885 & 0.933 & 0.900 & 0.867 & 0.875 & 0.869 & 0.905 & 0.931 & 0.821 \\
\hline $\mathrm{Na}$ & 0.025 & 0.027 & 0.032 & 0.018 & 0.024 & 0.042 & 0.026 & 0.028 & 0.040 & 0.000 \\
\hline $\mathrm{Ca}$ & - & - & - & - & - & - & - & - & 0.003 & 0.014 \\
\hline $\mathrm{OH}^{-}$ & 2.000 & 2.000 & 2.000 & 2.000 & 2.000 & 2.000 & 2.000 & 2.000 & 2.000 & 2.000 \\
\hline $\mathrm{Al}_{\mathrm{gen}}$ & 2.718 & 2.688 & 2.567 & 2.632 & 2.747 & 2.762 & 2.723 & 2.852 & 2.831 & 2.797 \\
\hline$f e$ & 0.717 & 0.688 & 0.681 & 0.650 & 0.376 & 0.368 & 0.351 & 0.421 & 0.554 & 0.774 \\
\hline
\end{tabular}

Note: An. 1-4 - sam. MN-2, an. 5-8 - sam. MT-4, an. 9 - sam. MN-7, an. 10 - sam. MN-33. bdl - below detection limits by the electron micrpoprobe. $\mathrm{fe}=\mathrm{Fe} /(\mathrm{Fe}+\mathrm{Mg}) . \mathrm{H}_{2} \mathrm{O}$ grade is calculated using stoichiometry.

Примечание: ан. 1-4 - обр. МН-2, ан. 5-8 - обр. МН-4, ан. 9 - обр. МН-7, ан. 10 - обр. МH-33; bdl (н.п.о.) - ниже предела обнаружения электронно-зондовым методом; $f e=\mathrm{Fe} /(\mathrm{Fe}+\mathrm{Mg})$. Содержание $\mathrm{H}_{2} \mathrm{O}$ рассчитано по стехиометрии.

of calculations. The location of compositions on the triangular diagram in terms of Fe-Al- $\mathrm{Mg}$ (Fig. 2d) above schorl-dravite line indirectly indicate the Fe low content.

The excess charge versus $\mathrm{Mg}+\mathrm{Fe}+\mathrm{X}$-vacancy plot (Fig. 2c) indicates that the chemical substitution of $\mathrm{Al}+\mathrm{O}^{2-} \leftrightarrow \mathrm{R}+\mathrm{OH}^{-}$is exposed in dravite, where $\mathrm{R}=\mathrm{Fe}^{2+}$, $\mathrm{Mg}$.

White mica forms aggregates of small scales between tourmaline crystals (Fig. 4b). Chemically, mica refers to muscovite (Table 2, an. 9). The Fe and Mg contents are 0.11 and 0.09 apfu, respectively.

Tourmaline-bearing assemblages of the Kulibinsky site are quartz-tourmaline metasomatites (sample MN-33); it appears to form a linear zone in volcanic rocks. Metasomatites are dissected by veinlets of late quartz with $1-4 \mathrm{~cm}$ thick. The veinlets are composed of coarse-grained parallel-columnar quartz, the color of which varies from lacteous to lilaceous.

Tourmaline forms dense, almost monomineralic aggregates of acicular crystals and is represented by two generations. The first generation tourmaline is composed of relatively large, complexly zoned crystals ranging in size from $100 \mu \mathrm{m}$ to a few $\mathrm{mm}$ (Fig. 5a, b). It contains fine inclusions of W-bearing rutile and REE phosphates. The second generation tourmaline is represented by small individual crystals up to $20 \mu \mathrm{m}$ in diameter (Fig. 5b, c); as an aggregate of split crystals, it molds on tourmaline I (Fig. 5d) or forms the outer zones on tourmaline crystals of the first generation (Fig. 5b).

Large crystals of tourmaline-I are pleochroic from brown or dark blue to black. The BSE images (Fig. 5a, b) show their complex zonality due to the variable Fe content. Zonality is especially well exhibited along the long axis (Fig. 5a). Crystallization begins with the formation of Fe-rich tourmaline $(\mathrm{Fe} /(\mathrm{Fe}+\mathrm{Mg})$ 0.55-0.77 (Table 1). Then ferriferous acquires a rhythmic character varying in wide range from 0.41 to 0.71 . Chemically, tourmaline-I is confined to the alkali series (Fig. 2a) and can be referred to schorl, but composition - to dravite. However, it should be noted that establishing the concentration of $\mathrm{Fe}^{3+}$ in the mineral can 

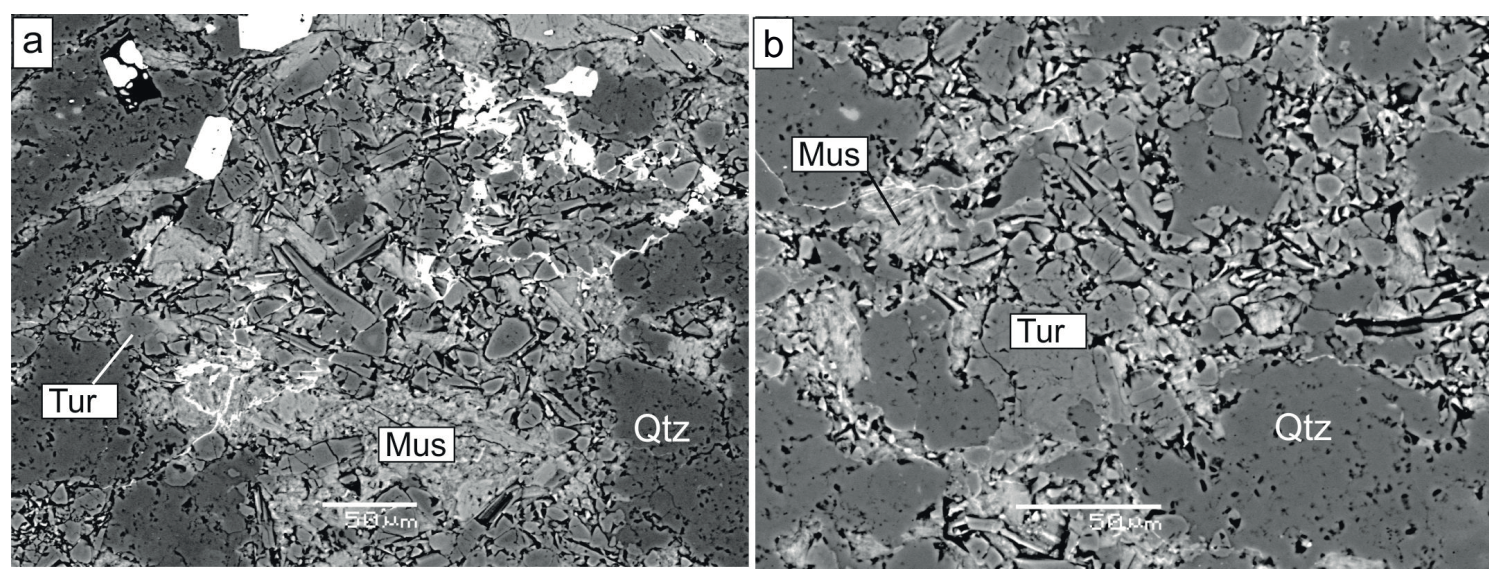

Figure 4. Muscovite-tourmaline aggregate cementing brecciated quartz crystals. The photo "a" shows small zonal crystals of tourmaline. The Zamanchivy site, MN-7 sample. Photo in back scattered electrons.

Рисунок 4. Мусковит-турмалиновый агрегат, цементирующий брекчированные кристаллы кварца. На фото «а» видны мелкие зональные кристаллы турмалина. Участок Заманчивый, образец МН-7. Фото в отраженных электронах.
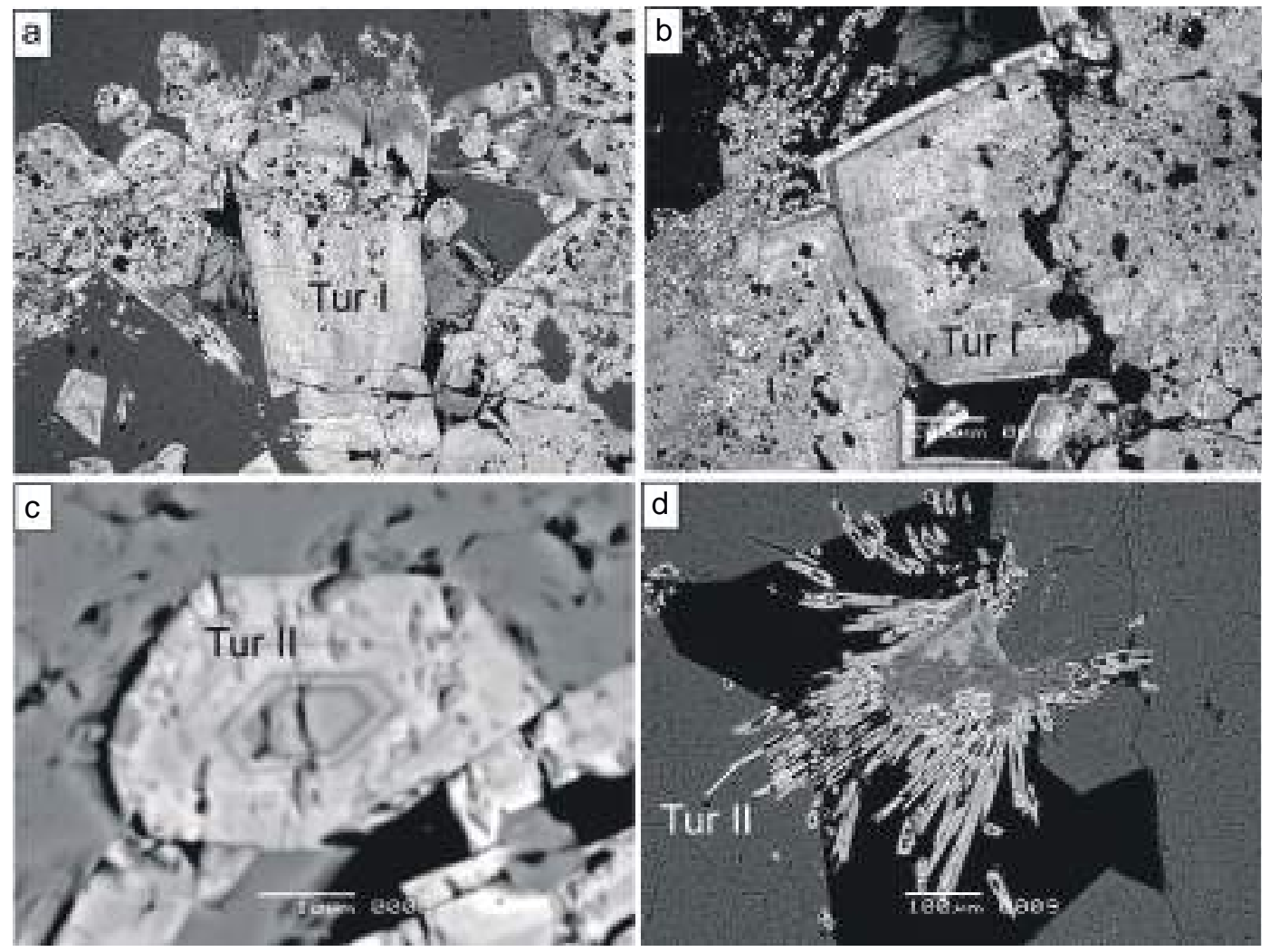

Figure 5. Two generations of tourmaline crystals of quartz-tourmaline metasomatites. a, b-relatively large, complex and zonal tourmalinecrystals. Their growth, in general, occurred with a decrease in ferrous; tourmaline contains growths of W-bearing rutile and REE phosphates; c - small zonal tourmaline-II crystal; $d$-aggregate of split tourmaline-II crystals molds on zonal tourmaline-I. The Kulibinsky site, MN-33 sample. Photo in back scattered electrons.

Рисунок 5. Две генерации кристаллов турмалина кварц-турмалиновых метасоматитов. a, b - относительно крупные, сложно-зональные кристаллы турмалина-I, рост которых в целом происходил с уменьшением железистости, турмалин содержит вростки W-содержащего рутила и фосфатов РЗЭ; с - мелкий зональный кристалл турмалина-II; d - агрегат расщепленных кристаллов турмалина-ІІ нарастает на зональный турмалин-І. Участок Кулибинский, образец МН-33. Фото в отраженных электронах.

change its classification. Schorl contains up to 0.16 apfu Ti; Ca concentration is $0.10-0.37$ apfu. The Mn content in most compositions is less-than-detection limits; sometimes, it is 0.01-0.02 apfu.

Second-generation tourmaline crystals are also pleochroic from brown or dark blue to black. In contrast to the first-generation schorl crystals, they have the usual growth zonality with a darker central part and a lighter outer zone (Fig. 5b, c). The central parts of crystals are composed of foitite, the edge parts can be confined to schorl. However, establishing the concentration of $\mathrm{Fe}^{3+}$ in the mineral can change its classification. Such a change is more likely to take place because the tourmaline edge zones are characterized by a significant deficit of positive charges (when calculating a formula for 15 cations, where iron is considered as ferrous). The calculated amount of $\mathrm{Fe}^{3+}$ in the edge zones of tourmaline-II crystals is $0.43-1.78 \mathrm{apfu}$. In the diagram in terms of 
of the excess charge $-\mathrm{Mg}+\mathrm{Fe}+{ }^{\mathrm{x}} \square \square$ (Fig. 2c), two imaging points of compositions are located near the bosiite point, tourmaline with the ideal formula $\mathrm{NaFe}_{3}^{3+}\left(\mathrm{Mg}_{2} \mathrm{Al}_{4}\right)\left[\mathrm{Si}_{6} \mathrm{O}_{18}\right]\left(\mathrm{BO}_{3}\right)(\mathrm{OH})_{3} \mathrm{O}[13]$.

The same graph as well as diagrams in Fig. $2 \mathrm{c}$, e, g show that tourmaline of both generations is characterized by substitution of $\mathrm{Fe}^{3+} \leftrightarrow \mathrm{Al}$. Indirectly, the location of a number of imaging composition points below schorl-dravite line on the triangular diagram in terms of $\mathrm{Fe}-\mathrm{Al}-\mathrm{Mg}$ (Fig. 2d) indicate the enrichment of $\mathrm{Fe}^{3+}$ tourmaline.

White mica composes colorless scales of several hundred microns in size. Chemically, it refers to muscovite (Table 2, an. 10). The Fe and Mg contents are 0.18 and 0.05 apfu, respectively. Muscovite does not contain F.

Discussion

The obtained data show that tourmalines of the Mnogovershinnoe deposit differ in their chemical composition and type of substitution. All studied tourmalines by these parameters can be divided into two groups.

Group 1 includes schorl, foitite and pegmatoids feruvite (sam. MN-2), as well as schorl and foitite of the first generation, tourmaline-muscovite-quartz veinlet in sandstones (sam. MN-4). Group 2 includes the second generation schorl, tourmaline-muscovite-quartz veinel (sam. MN-4), schorl and foitite of quartz-tourmaline metasomatites (sam. MN-33) and dravite of quartz breccia cement (sam. MN-7).

For tourmaline of the first group, substitutions $\mathrm{Fe} \leftrightarrow \mathrm{Mg}$ and $\mathrm{X}$-vacancy $+\mathrm{Al} \leftrightarrow \mathrm{Na}+\mathrm{R}^{2}+$ are common, with the secondary role of replacing $\mathrm{Al}+\mathrm{O}^{2-} \leftrightarrow \mathrm{R}^{2+}+\mathrm{OH}^{-}$, except for single sectors of crystals enriched in $\mathrm{Ca}$. One more fact that allows us to combine these tourmalines is the increased $\mathrm{Zn}$ and $\mathrm{Mn}$ content compared with group 2. The large size of quartz-muscovite veinlets of tourmaline-I crystals in sandstones and the chemical composition identical to tourmaline of pegmatoids implies that these veinlets are pegmatoids as well. The charge-balanced chemical formulas of tourmaline do not even allow an approximate estimate the ratio of $\mathrm{Fe}^{3+} / \mathrm{Fe}_{\text {total }}$ in tourmaline, which indicates a low $\mathrm{Fe}^{3+}$ grade in the mineral or its absence. In turn, this indicates reducing or slightly oxidative conditions for the formation of tourmaline and pegmatoids in general. According to [14], the ratio $\mathrm{Fe}^{3+} / \mathrm{Fe}_{\text {tot }}$ in tourmaline of pegmatites is $0.05-0.22$.

For tourmaline of the second group, substitutions $\mathrm{Fe}^{3+} \leftrightarrow \mathrm{Al}$ and $\mathrm{Al}+\mathrm{O}^{2-} \leftrightarrow \mathrm{R}^{2+}+\mathrm{OH}^{-}$are common, which is typical of tourmalines from porphyry-style deposits [15]. The formulas of tourmalines of quartz-tourmaline metasomatites calculated using the electron probe analysis are not balanced in charges, which makes it possible to approximately estimate the ratio $\mathrm{Fe}^{3+} / \mathrm{Fe}_{\text {tot }}$. In tourmaline of quartz-tourmaline metasomatites, it varies from 0.01 to 0.48 indicating the enrichment of $\mathrm{Fe}^{3+}$ in a number of compositions and the increased oxidative potential of mineral formation environment. The location of points below the line of schorl-dravite on a triangular diagram (Fig. 2d) indirectly indicates the enrichment of tourmaline compounds with ferric iron. The calculated ratio $\mathrm{Fe}^{3+} / \mathrm{Fe}_{\text {total }}$ in tourmaline-II quartz veinlets in sandstones and tourmaline cement quartz breccia does not exceed 0.08 giving evidence of more reducing conditions of formation than in the case of quartz-tourmaline metasomatites. The imaging points of these tourmalines are located above the schorl-dravite line on the triangular diagram indirectly indicating a low content of $\mathrm{Fe}^{3+}$ in minerals. The obtained data suggest that the formation of tourmaline of the second group took place against the background of a decrease in the oxidative potential of the mineral formation environment.

Conclusion

Tourmalines of the post-ore mineral associations of the Mnogovershinnoe gold deposit are divided into two groups characterized by different chemical composition and substitutions. Tourmalines of the first group with substitutions Fe $\leftrightarrow \mathrm{Mg}$ and $\mathrm{X}$-vacancy $+\mathrm{Al} \leftrightarrow \mathrm{Na}+\mathrm{R}^{2+}$ are confined to pegmatoids and were formed in reductive or slightly oxidative conditions. Later tourmalines of the second group with substitutions $\mathrm{Fe}^{3+} \leftrightarrow \mathrm{Al}$ and $\mathrm{Al}+\mathrm{O}^{2-} \leftrightarrow \mathrm{R}^{2+}+\mathrm{OH}^{-}$indicate the possible presence of mineralization of the porphyry type and the formation of a mineralization while reducing the oxidation potential of mineral formation environment.

Acknowledgments

The authors are grateful to N. N. Koshlyakova for her assistance in electron microprobe study.

\section{REFERENCES}

1. Henry D. J., Novák M., Hawthorne F. C., Ertl A., Dutrow B. L., Uher P., Pezzotta F. 2011, Nomenclature of the tourmaline-supergroup minerals. American Mineralogist, vol. 96, pp. 895-913. https://doi.org/10.2138/am.2011.3636

2. Kuzmin V. I., Dobrovolskaya N. V., Solntseva L. S. 1979, Turmalin i yego ispol'zovaniye pri poiskovo-otsenochnykh rabotakh [Tourmaline and its use in prospecting]. Moscow, $272 \mathrm{p}$.

3. Collins A. C. 2010, Mineralogy and geochemistry of tourmaline in contrasting hydrothermal systems: Copiapó area, Northern Chile. Unpub. Master thesis, Univ. Arizona, $225 \mathrm{p}$.

4. Slack J. F. 1996, Tourmaline associations with hydrothermal ore deposits. Reviews in Mineralogy, vol. 33, pp. 559-643.

5. Moiseenko V. G., Eyrish L. G. 1996, Zolotorudnyye mestorozhdeniya vostoka Rossii [Gold deposits of the east of Russia]. Vladivostok, $360 \mathrm{p}$.

6 . Ratkin V. V. 1995, Pre- and postaccretionary metallogeny of the Southern Russian Far East. Resource Geology, no 18, pp. 127-133. https:// doi.org/10.1127/0935-1221/2012/0024-2241

7. Nokleberg W. J. 2010, Metallogenesis and tectonics of the Russian Far East, Alaska, and the Canadian Cordillera. U.S. Geological Survey, 397 p.

8. Kazarinov A. I., Mikhailova M. S. 1970, Relationships of gold and gold-silver mineralization with propylites, secondary quartzites and quartz metasomatites (using the group of subvolcanic deposits of the East of the USSR as an example). Izvestiya Tomskogo politekhnicheskogo instituta [Bulletin of the Tomsk Polytechnic University], vol. 239, pp. 50-54. (In Russ.)

9. Konstantinov M. M., Vargunina N. P., Kosovets T. N., Struzhkov S. F., Syngayevskiy E. D., Shishakova L. N. 2000, Zoloto-serebryanyye mestorozhdeniya [Gold and silver deposits]. Series: fields models noble and non-ferrous metals. Moscow, $239 \mathrm{p}$.

10. Ivanov V. V., Zinkov A. V., Taskaev A. V. 1989, Mineralogiya pozdnepaleogenovykh zoloto-serebryanykh mestorozhdeniy v rayone Nizhnego Amura [Mineralogy of Late Paleogene gold-silver deposits in the area of Nizhni Amur]. Collection of works: Typical minerals of ore deposits in volcanic belts and zones of activation of northeast Asia. Vladivostok, pp. 87-89.

11. Jarozewich E. 2002, Smitsonian microbeam standards. Journal of Research of the National Institute of Standards and Technology, vol. 107, pp. 681-685. https://dx.doi.org/10.6028/jres.107.054

12. Henry D. J., Kirkland B. L., Kirkland D. W. 1999, Sector-zoned tourmaline from the cap rock of a salt dome. European Journal of Mineralogy, vol. 11, pp. 263-280.

13. Ertl A., Baksheev I. A., Giester G., Lengauer C. L., Prokofiev V. Yu., Zorina L. D. 2016, Bosiite, $\mathrm{NaFe}_{3}^{3+}\left(\mathrm{Al}_{4} \mathrm{Mg}_{2}\right)\left(\mathrm{Si}_{6} \mathrm{O}_{18}\right)\left(\mathrm{BO}_{3}\right)_{3}(\mathrm{OH})_{3} \mathrm{O}$, a new ferric member of the tourmaline supergroup from the Darasun gold deposit, Transbaikalia, Russia. European Journal of Mineralogy, vol. 28, pp. 581-591. https://doi.org/10.1127/ejm/2016/0028-2540 
14. Korovushkin V. V., Kuzmin V. I., Belov V. F. 1979, Mössbauer studies of structural features in tourmaline of various genesis. Physics and Chemistry of Minerals, vol. 4, pp. 209-220. https://doi.org/10.1007/BF00307945

15. Baksheev I. A., Prokof'ev V. Yu., Zaraisky G. P., Chitalin A. F., Yapaskurt V. O., Nikolaev Y. N., Tikhomirov P. L., Nagornaya E. V., Rogacheva L. I., Gorelikova N. V., Kononov O. V. 2012, Tourmaline as a prospecting guide for the porphyry-style deposits. European Journal of Mineralogy, vol. 24, pp. 957-979. https://doi.org/10.1127/0935-1221/2012/0024-2241 


\title{
О химизме турмалина из Многовершинного рудного поля (Хабаровский край, Аамьний Восток)
}

\author{
Иван Андреевич БАКШЕЕВ \\ Евгений Алексеевич ВЛАСОВ
}

Московский государственный университет им. М. В. Ломоносова, Россия, Москва

Актуальность работы обусловлена необходимостью изучения минералогии золоторудных объектов $\Delta$ аиьнего Востока, сведения о которых крайне скудны.

Цель работы: исседование химического состава турмалина из Многовершинного рудного поля, Хабаровский край (Аамьний Восток).

Методология исследования: химический состав минералов и их изображение были получены с помошью электронного микроскопа Јеоl JSM6480, оборудованного энергодисперсионной приставкой Inca Energy-350 (аналитик Н. Н. Кошлякова, каселра петрологии МГУ). Условия съемки на электронном микроскопе: ускоряюшее напряжение 15 кВ, ток зонда на образце $30 \pm 0,1$ нА. Аия процедуры коррекции использованы ХРР поправки (программа "INCA" версия 17a).

Результаты. Полученные Аанные показывают, что турмалины Многовершинного рудного поля различаются по химическому составу и характеру

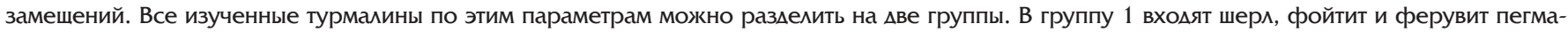
тоидов, а также шерл и сойтит первой генерации турмалин-мусковит-кварцевого прожилка в песчаниках. В группу 2 попадают шерл второй генерации турмалин-мусковит-кварцевого прожилка, шерл и фойтит кварц-турмалиновых метасоматитов и Аравит цемента кварцевой брекчии. Выводы. Турмалины послерудных минеральных ассоциаций Многовершинного золоторудного месторождения делятся на две группы, характеризуюшиеся разным химическим составом и замешениями. Турмахины первой группы C замешениями $\mathrm{Fe} \leftrightarrow \mathrm{Mg}$ и $\mathrm{X}$-вакансия $+\mathrm{Al} \leftrightarrow \mathrm{Na}+\mathrm{R}^{2+}$ относятся к пегматоилам и формировамись в восстановительных или слабоокислительных условиях. Более поздние турмалины второй группы с замешениями $\mathrm{Fe}^{3+} \leftrightarrow \mathrm{Al}$ и $\mathrm{Al}+\mathrm{O}^{2-} \leftrightarrow \mathrm{R}^{2+}+\mathrm{OH}^{-}$указывают на возможное намичие минерамизации порсирового типа и сормирование при снижении окислительного потенциала среды минералообразования.

Киючевые слова: турмамин, химический состав, метасоматиты, Многовершинное рудное поле, Хабаровский край, Аамьний Восток.

\section{ЛИТЕРАТУРА}

1. Henry D. J., Novák M., Hawthorne F. C., Ertl A., Dutrow B. L., Uher P., Pezzotta F. Nomenclature of the tourmaline-supergroup minerals /I American Mineralogist. 2011. Vol. 96. P. 895-913. https://doi.org/10.2138/am.2011.3636

2. Кузьмин В. И., Добровольская Н. В., Солнцева Л. С. Турмалин и его использование при поисково-оценочных работах. М.: Недра, 1979. 272 с. 3.Collins A. C. Mineralogy and geochemistry of tourmaline in contrasting hydrothermal systems: Copiapó area, Northern Chile. Unpub. Master thesis, Univ. Arizona, 2010. 225 p.

4. Slack J. F. Tourmaline associations with hydrothermal ore deposits // Reviews in Mineralogy. 1996. Vol. 33. P. 559-643.

5. Моисеенко В. Г., Эйриш Л. Г. Золоторудные месторождения Востока России. Владивосток: Дальнаука, 1996. 360 с.

6. Ratkin V. V. Pre- and post-accretionary metallogeny of the Southern Russian Far East // Resource Geology. 1995. № 18. P. 127-133. https:// doi.org/10.1127/0935-1221/2012/0024-2241

7. Nokleberg W. J. Metallogenesis and tectonics of the Russian Far East, Alaska, and the Canadian Cordillera. Reston, Virginia, United States.

U. S. Geological Survey. 2010. 397 p.

8. Казаринов А. И., Михайлова М. С. Взаимоотношения золотого и золото-серебряного оруденения с пропилитами, вторичными кварцитами и кварцевыми метасоматитами (на примере группы субвулканических месторождений Востока СССР // Изв. ТПИ. 1970. Т. 239. C. $50-54$.

9. Константинов М. М., Варгунина Н. П., Косовец Т. Н., Стружков С. Ф., Сынгаевский Е. Д., Шишакова Л. Н. Золото-серебряные месторождения. Сер. «Модели месторождений благородных и цветных металлов». М.: ЦНИГРИ, 2000. 239 с.

10. Иванов В. В., Зиньков А. В., Таскаев А. В. Минералогия позднепалеогеновых золото-серебряных месторождений в районе Нижнего Амура // Типовые минералы рудных месторождений в вулканических поясах и зонах активизации Северо-Восточной Азии. Владивосток: ДВГИ АН СССР, 1989. С. 87-89.

11. Jarozewich E. Smitsonian microbeam standards // Journal of Research of the National Institute of Standards and Technology. 2002. Vol. 107. P. 681-685. https://dx.doi.org/10.6028/jres.107.054

12. Henry D. J., Kirkland B. L., Kirkland D. W. Sector-zoned tourmaline from the cap rock of a salt dome // European Journal of Mineralogy. 1999. Vol. 11. P. 263-280.

13. Ertl A., Baksheev I. A., Giester G., Lengauer C. L., Prokofiev V. Yu., Zorina L. D. Bosiite, $\mathrm{NaFe}^{3+}{ }_{3}\left(\mathrm{Al}_{4} \mathrm{Mg}_{2}\right)\left(\mathrm{Si}_{6} \mathrm{O}_{18}\right)\left(\mathrm{BO}_{3}\right)_{3}(\mathrm{OH})_{3} \mathrm{O}$, a new ferric member of the tourmaline supergroup from the Darasun gold deposit, Transbaikalia, Russia // European Journal of Mineralogy. 2016. Vol. 28. P. 581-591. https://doi.org/10.1127/ejm/2016/0028-2540

14. Korovushkin V. V., Kuzmin V. I., Belov V. F. Mössbauer studies of structural features in tourmaline of various genesis // Physics and Chemistry of Minerals. 1979. Vol. 4. P. 209-220. https://doi.org/10.1007/BF00307945

15. Baksheev I. A., Prokof'ev V. Yu., Zaraisky G. P., Chitalin A. F., Yapaskurt V. O., Nikolaev Y. N., Tikhomirov P. L., Nagornaya E. V., Rogacheva L. I., Gorelikova N. V., Kononov O. V. Tourmaline as a prospecting guide for the porphyry-style deposits // European Journal of Mineralogy. 2012. Vol. 24, № 6. P. 957-979. https://doi.org/10.1127/0935-1221/2012/0024-2241

baksheev@geol.msu.ru

https://orcid.org/0000-0001-6920-427X

user420@geol.msu.ru

38 Бакшеев И. А., Власов Е. А. О химизме турмалина из Многовершинного рудного поля (Хабаровский край, Дальний Восток) // Известия УГГУ. 2019. Вып. 1(53). C. 28-38. DOI 10.21440/2307-2091-2019-1-28-38 